\title{
Efficacy and tolerability of vitamin $C$ as an add on therapy to standard antihypertensive regimen
}

\author{
Vivek Singh $^{1}$, Ujjwal Sourav ${ }^{2 *}$
}

\begin{abstract}
${ }^{1}$ Department of Pharmacology, ${ }^{2}$ Department of Community medicine, Saraswathi Institute of medical sciences, Hapur, Uttar Pradesh, India
\end{abstract}

Received: 11 November 2020

Accepted: 15 December 2020

*Correspondence:

Dr. Ujjwal Sourav,

Email: ujjwalsourav2@gmail.com

Copyright: () the author(s), publisher and licensee Medip Academy. This is an open-access article distributed under the terms of the Creative Commons Attribution Non-Commercial License, which permits unrestricted non-commercial use, distribution, and reproduction in any medium, provided the original work is properly cited.

\begin{abstract}
Background: In both developing and developed countries, elevated arterial blood pressure is perhaps the most significant public health issue. It is widespread, often asymptomatic, readily observable, typically easily treatable and, if left untreated, frequently leads to lethal complications. According to the Framingham report, the prevalence of hypertension in the white suburban population is almost one-fifth of those with blood pressure $>160 / 95 \mathrm{~mm} \mathrm{Hg}$, while almost half of those with blood pressure $>140 / 90 \mathrm{~mm} \mathrm{Hg}$. Aim and objectives were to estimate the efficacy of vitamin $\mathrm{C}$ as an add-on therapy to the antihypertensive regimen.

Methods: The prospective comparative study was undertaken in mild to moderate hypertensive patients to find out the efficacy and tolerability of vitamin $\mathrm{C}$ as an add-on therapy to the standard anti-hypertensive regimen in the reduction of blood pressure and C-reactive protein levels. This study was done at the Saraswathi institute of medical sciences, Hapur, UP.

Results: For Systolic BP as well as DBP, at baseline there was non-significant difference among all the four group with $\mathrm{p}$ value 0.28 , whereas at all the visit at 1,3 and 6 month there was significant difference among the four group with $\mathrm{p}$ value $<0.01,<0.001$ and $<0.001$.

Conclusions: There was significant addon benefit of vit $\mathrm{C}$ when added with standard antihypertensive regimen.
\end{abstract}

Keywords: Adenomysis, Abnormal uterin bleeding, MR hysterography

\section{INTRODUCTION}

In both developing and developed countries, elevated arterial blood pressure is perhaps the most significant public health issue. It is widespread, often asymptomatic, readily observable, typically easily treatable and, if left untreated, frequently leads to lethal complications. According to the Framingham report, the prevalence of hypertension in the white suburban population is almost one-fifth of those with blood pressure $>160 / 95 \mathrm{~mm} \mathrm{Hg}$, while almost half of those with blood pressure $>140 / 90 \mathrm{~mm}$ $\mathrm{Hg}$. The incidence is closely linked to age in females, with a large increase occurring after the age of 50. This rise is probably due to menopausal hormonal shifts. The hypertension incidence ratio in women to men therefore rises from 0.6 to 0.7 at the age of 30 to 1.1 to 1.2 at the age of $65 .^{1}$

In 2005, 2.3 million deaths were caused by cardiovascular diseases in India and this is expected to double by 2020 . Hypertension is directly responsible for 57 percent of all deaths from strokes and 24 percent of all deaths in India from coronary artery disease. In India, the prevalence of hypertension was found to be 24 percent among men and 17 percent among women in $2007 .^{2}$

Hypertension is known to occur when a person's systolic blood pressure is consistently greater than or equal to 140 
$\mathrm{mm} \mathrm{Hg}$ and/or their diastolic blood pressure is consistently greater than or equal to $90 \mathrm{~mm} \mathrm{Hg}$. The seventh report of the joint national committee on the prevention, diagnosis, assessment and treatment of high blood pressure recently identified pre-hypertension as blood pressure from 120/80 $\mathrm{mm} \mathrm{Hg}$ to $139 / 89 \mathrm{~mm} \mathrm{Hg}$. Pre-hypertension is not a form of illness; rather, it is a classification selected to classify. ${ }^{3}$

Different symptoms will arise from untreated hypertension. Hypertension complications are associated either with sustained elevations in blood pressure, with consequent changes in the vasculature and heart, or with atherosclerosis preceded and accelerated by long-standing hypertension. Cardiac disorders are the primary causes of hypertension morbidity and mortality and a major aim of therapy is to avoid them. Left ventricular hypertrophy, left ventricular dysfunction, congestive heart failure, ventricular arrhythmia, myocardial infarction and sudden death are cardiac complications of hypertension. ${ }^{4}$

Other complications of hypertension include stroke, especially intracerebral haemorrhage and ischaemic cerebral infarction, hypertensive retinopathy, hypertensive nephropathy, aortic dissection, etc. Many groups of theoretically available anti-hypertensive drugs are now available, five of which (ACE inhibitors, diuretics, beta blockers, calcium channel blockers, and angiotension receptor blockers (ARBs) are ideal for efficacy and tolerability-based single drug therapy. The first line of drug therapy of choice for the treatment of hypertension is ACE inhibitors. ${ }^{5}$

It is increasingly recognised that inflammation and its mediators are involved in hypertension, cardiovascular pathophysiology, and atherogenesis. Inflammatory molecular plasma levels such as C-reactive protein (CRP); cytokines such as tumour necrosis factor- (TNF-) and interleukin-6 (IL-6); chemokines such as monocyte chemoattractant protein (MCP-1); and adhesion molecules, such as P-selectin and In patients with critical hypertension, leukocyte adhesion molecules, intercellular adhesion molecules (ICAM-1) are increased and increased CRP level has also been reported to be a predictor of potential cardiovascular diseases such as coronary artery disease occurrence, myocardial infarction and stroke. ${ }^{7-9}$

In reducing the levels of C-reactive protein, which is a stronger indicator of potential cardiovascular and cerebrovascular risks, none of the standard antihypertensive medicines have been found to be successful. As a good reducing agent, vitamin $\mathrm{C}$, one of the watersoluble vitamins, protects different organs against oxidising agents and decreases the oxidation of lowdensity lipoproteins and prevents atheromatous plaque deposition and the occurrence of stroke. It helps to preserve vascular integrity through the effects of prostacyclines, antiplatelets, and vasodilators. By enhancing nitric oxide production in hypertensive patients, vitamin $\mathrm{C}$ improves endothelial based vasodilation. ${ }^{10}$
This prospective comparative study is therefore undertaken to evaluate the effectiveness of vitamin $\mathrm{C}$ in blood pressure as an addition to therapy in the regular antihypertensive regimen.

\section{Aims and objectives}

Aim and objectives were 1) this study is for estimate the efficacy of vitamin $\mathrm{C}$ as an add-on therapy to the antihypertensive regimen 2) this study is for examine the tolerability of vitamin $\mathrm{C}$ as an add-on therapy to the standard anti-hypertensive regimen in the management of mild to moderate hypertension.

\section{METHODS}

The study was undertaken in mild to moderate hypertensive patients to find out the efficacy and tolerability of vitamin $\mathrm{C}$ as an add-on therapy to the standard anti-hypertensive regimen in the reduction of blood pressure and C-reactive protein levels. This study was done at the Saraswathi institute of medical sciences, Hapur, UP

\section{Study design}

This study was a comparative prospective study.

\section{Study centre}

Saraswathi Institute of medical sciences, Hapur, UP

\section{Study period}

The study was carried out from November 2019 to Sept 2020 .

\section{Study population}

Patients attending the outpatient department of Department of Internal Medicine, Saraswathi Institute of medical sciences, Hapur

\section{Sample size}

\section{0 patients}

\section{Inclusion criteria}

Inclusion criteria were 1) patients in the age group of 1865 years 2) patients with mild to moderate hypertension 3 ) patients with body mass index (BMI) of 18-25

\section{Exclusion criteria}

Exclusion criteria were 1) patients with any other active infection 2) patients with any history of surgery in the recent past 3 months 3) patients with history of malignancies 4) patients with evidence of gastrointestinal 
tract, renal, endocrine, cardiovascular abnormalities and any other major systemic illness 5) pregnant and lactating women

The study commenced after obtaining approval from the Institutional ethical committee.

\section{Patient recruitment}

The study method, purpose and its benefits were explained in detail to patients who attended the out-patient Department, Department of Internal Medicine, Saraswathi Institute of Medical Sciences, Hapur,

Written informed consent was obtained in the specified format in the regional language prior to the execution of the research procedures from patients willing to participate in the study. If the patient is illiterate, look for a left thumb impression.

This was done in the presence of impartial witness. Patients advised to come on next day at 8.00 A.M on empty stomach for screening procedure.

\section{Baseline visit}

Detailed medical history, blood pressure monitoring, estimation of C-reactive protein levels, physical and systemic evaluation and baseline demographic characteristics were reported for patients who gave written informed consent to participate in the study. For the haematological and serum biochemical tests, blood was drawn. We screened 580 patients.

\section{Recruitment and grouping}

Among 580 patients screened, 120 patients who fulfilled the inclusion and exclusion criteria were recruited for the study. The recruited 120 patients were randomized into four groups each consisting of 30 patients.

\section{Grouping}

Group 1: Enalapril 5 mg BD

Group 2: Enalapril 5 mg BD +vitamin C 100 mg OD

Group 3: Enalapril 5 mg BD +vitamin C 250 mg OD

\section{Group 4: Enalapril 5 mg BD + vitamin C 500 mg OD}

Total 120 patients with systolic blood pressure in the 140$179 \mathrm{~mm} \mathrm{Hg}$ range and diastolic blood pressure in the 90$109 \mathrm{~mm} \mathrm{Hg}$ range with C-reactive protein levels in the 10$12 \mathrm{mg} / \mathrm{dl}$ range were recruited for the study out of 580 patients screened.

1) patient were given medication for two weeks 2) instructed to come fortnightly to collect the medication 3 ) patients were instructed to bring the empty foils at the end of 2 weeks to check the patients compliance 4) patient's blood pressure was recorded 5) detailed medical history and clinical examination was done 6) blood samples were collected for the estimation of C-reactive protein levels and routine hematological and biochemical parameters 7) patients were advised to report to the investigator as soon as possible in case of occurrence of any adverse effects 8) patients were instructed to report to the investigator in case of occurrence of any other illness and intake of other medications for the same. This study was undertaken to find out the efficacy and tolerability of vitamin $\mathrm{C}$ as an add-on therapy to the standard anti-hypertensive regimen.

\section{RESULTS}

Out of 580 patients screened, 120 patients who fulfilled the inclusion and exclusion criteria were recruited for the study. They were randomized into four groups, group 1, group 2, group 3 and group 4, each consisting of 30 patients.

Table 1: Distribution of study subjects as per age.

\begin{tabular}{|c|c|c|c|c|}
\hline Groups & $\mathbf{N}$ & Mean & $\begin{array}{l}\text { Std. } \\
\text { deviation }\end{array}$ & $\begin{array}{l}\text { ANOVA } \\
\text { F-test }\end{array}$ \\
\hline Group 1 & 30 & 43.96 & 7.613 & \multirow{5}{*}{$\begin{array}{l}\mathrm{F}=0.49 \\
\mathrm{P}=0.69 \\
\text { Not } \\
\text { Significant }\end{array}$} \\
\hline Group 2 & 30 & 45.30 & 8.203 & \\
\hline Group 3 & 30 & 46.50 & 7.550 & \\
\hline Group 4 & 30 & 45.04 & 7.881 & \\
\hline Total & 120 & 45.20 & 7.758 & \\
\hline
\end{tabular}

Table 1 shows distribution of study subjects as per age. In group 1, mean age was 43.96 \pm 7.61 , group II 45.30 \pm 8.203 , group III $46.5 \pm 7.55$ whereas in group $445.04 \pm 7.88$. On comparison we found non-significant difference with $\mathrm{P}$ value.

Table 2: Comparison of SBP among all four group at different visit.

\begin{tabular}{|c|c|c|c|c|c|c|c|c|c|}
\hline \multirow{3}{*}{ Parameter } & \multicolumn{8}{|l|}{ Groups } & \multirow{3}{*}{ Test of significance } \\
\hline & \multicolumn{2}{|c|}{ Group 1} & \multicolumn{2}{|c|}{ Group 2} & \multicolumn{2}{|c|}{ Group 3} & \multicolumn{2}{|c|}{ Group 4} & \\
\hline & Mean & SD & Mean & SD & Mean & SD & Mean & SD & \\
\hline Baseline SBP & 156.36 & 6.08 & 153.93 & 7.01 & 155.36 & 7.07 & 153.34 & 6.22 & $\mathrm{~F}=1.28 \mathrm{P}=0.28(\mathrm{NS})$ \\
\hline 1-month SBP & 152.36 & 5.24 & 147.28 & 6.16 & 146.67 & 6.37 & 143.04 & 7.29 & $\mathrm{~F}=11.09 \mathrm{P}<0.01(\mathrm{~S})$ \\
\hline 3-month SBP & 148.93 & 5.34 & 143.32 & 7.16 & 142.39 & 7.34 & 131.34 & 3.47 & $\mathrm{~F}=44.62, \mathrm{P}=0.001(\mathrm{~S})$ \\
\hline 6-month SBP & 136.39 & 7.27 & 126.32 & 17.77 & 119.37 & 19.54 & 118.68 & 3.42 & $\mathrm{~F}=10.65, \mathrm{P}=0.001(\mathrm{~S})$ \\
\hline
\end{tabular}


Table 3: Comparison of DBP among all four group at different visit.

\begin{tabular}{|c|c|c|c|c|c|c|c|c|c|}
\hline \multirow{3}{*}{ Parameter } & \multicolumn{8}{|l|}{ Group } & \multirow{3}{*}{ Significance } \\
\hline & \multicolumn{2}{|c|}{ Group 1} & \multicolumn{2}{|c|}{ Group 2} & \multicolumn{2}{|c|}{ Group 3} & \multicolumn{2}{|c|}{ Group 4} & \\
\hline & Mean & SD & Mean & SD & Mean & SD & Mean & SD & \\
\hline Baseline DBP & 89.98 & 3.75 & 88.87 & 3.12 & 89.08 & 3.01 & 90.03 & 3.47 & $\begin{array}{l}\mathrm{F}=0.96, \\
\mathrm{P}=0.41(\mathrm{NS})\end{array}$ \\
\hline 1-month DBP & 87.32 & 4.23 & 86.48 & 3.37 & 84.88 & 3.38 & 83.83 & 3.43 & $\begin{array}{l}\mathrm{F}=5.63 \\
\mathrm{P}=0.01(\mathrm{~S})\end{array}$ \\
\hline 3-month DBP & 83.79 & 3.64 & 83.11 & 2.88 & 82.97 & 2.67 & 78.28 & 2.17 & $\begin{array}{l}F=23.02 \\
P<0.01(S)\end{array}$ \\
\hline 6-month DBP & 80.78 & 4.22 & 79.88 & 3.16 & 77.48 & 3.13 & 74.82 & 2.17 & $\begin{array}{l}\mathrm{F}=20.25 \\
\mathrm{P}=0.001(\mathrm{~S})\end{array}$ \\
\hline
\end{tabular}

Table 2 shows comparison of SBP among all four group at different visit. At baseline there was non-significant difference among all the four group with $\mathrm{p}$ value 0.28 , whereas at all the visit at 1,3 and 6 month there was significant difference among the four group with $\mathrm{p}$ value $<0.01,<0.001$ and $<0.001$.

Table 3 shows comparison of DBP among all four group at different visit. At baseline there was no significant difference among different groups in diastolic BP, whereas there was significant difference among all four groups at all 3 visit i.e 1, 3 and 6 months with p value $<0.001$.

\section{DISCUSSION}

The study was conducted in the Outpatient Department of Department of Internal medicine, Saraswathi Institute of medical sciences, Hapur. Out of 580 patients screened, 120 patients who fulfilled the inclusion and exclusion criteria were recruited for the study. They were randomized into four groups, group I, group II, group III and group IV, each group consisting of 30 patients. Group I received Enalapril $5 \mathrm{mg} \mathrm{BD}$, group II received Enalapril $5 \mathrm{mg}$ BD with vitamin C $100 \mathrm{mg}$ OD, group III received enalapril $5 \mathrm{mg}$ BD with vitamin C $250 \mathrm{mg}$ OD and Group D Efficacy variables were assessed at baseline, at the end of the 1st month, at the end of the 3rd month, and at the end of the 6th month of the study, such as systolic blood pressure, diastolic blood pressure and $\mathrm{C}$ reactive protein levels. Other haematological studies such as full hemogram, blood sugar, blood urea, serum creatinine, measures of liver function such as SGOT, SGPT, serum alkaline phosphatase, total bilirubin, total protein, albumin were performed at baseline, at the end of the first month, at baseline, at the end of the first month received enalapril 5 $\mathrm{mg}$ BD with vitamin C $500 \mathrm{mg}$ OD for a period of 6 months causes statistical significant reduction of systolic blood pressure of $11.15 \%$ at the end of 1 st month, reduction of $18.29 \%$ at the end of 3rd month and $24.73 \%$ at the end of 6th month of the study.

At the end of the 1st month, 7.17 percent at the end of the 3rd month and 12.64 percent at the end of the 6th month of the study, 3.45 percent reduction in systolic blood pressure produced by Enalapril $5 \mathrm{mg}$ BD. One analysis, comparing vitamin C supplementation of $500 \mathrm{mg} /$ day for 1 month, showed a substantial decrease in systolic BP of $9.9 \mathrm{~mm}$ Hg. ${ }^{11}$ Another research found that once daily, vitamin $\mathrm{C}$ $500 \mathrm{mg}$ created a 9 percent drop in blood pressure after 4 weeks of study. ${ }^{12-14}$ In this study, when a dose of $500 \mathrm{mg}$ was given, with enalapril $5 \mathrm{mg}$ BD causes statistical significant reduction of diastolic blood pressure of $12.72 \%$ at the end of $3 \mathrm{rd}$ month and $15.73 \%$ at the end of 6 th month of the study. Enalapril $5 \mathrm{mg}$ BD alone group produces reduction of diastolic blood pressure of $7.08 \%$ at the end of 3rd month and $10.07 \%$ at the end of 6th month of the study. In our study, it has been found even though group III showed significant reduction of $\mathrm{C}$ reactive protein levels, only patients in group IV (vitamin C $500 \mathrm{mg}$ ) showed reduction of $\mathrm{C}$ reactive protein to the desirable level $(<1 \mathrm{mg} / \mathrm{dl})$.

In our study, it was observed that when administered with enalapril $5 \mathrm{mg} \mathrm{BD}$, vitamin $\mathrm{C}$ at a dosage of $500 \mathrm{mg}$ once daily induces a decrease in $\mathrm{C}$ reactive protein levels to 49.47 percent at the end of the 1 st month, 88.54 percent at the end of the 3rd month and 99.64 percent at the end of the 6th month, compared to enalapril $5 \mathrm{mg}$ OD alone, in which the decrease in $C$ reactive protein level was 0.27 percent at the end of the 6th month. One study showed that ingestion of vitamin C $250 \mathrm{mg} /$ day and $500 \mathrm{mg}$ /day showed significant reduction of $\mathrm{C}$ reactive protein levels at the end of 2 months.

Hence, it has been found even though vitamin C $100 \mathrm{mg}$ and $250 \mathrm{mg}$ group showed reduction of systolic and diastolic blood pressure, only patients in group 3 (vitamin C $500 \mathrm{mg}$ ) showed reduction of $\mathrm{C}$ reactive protein to desirable levels. Other hematological and biochemical parameters were measured at the baseline, at the end of $1 \mathrm{st}$ month, at the end of 3rd month and the end of 6th month and found to have no statistical difference among the study groups.

\section{CONCLUSION}

From our study, we conclude that vitamin $\mathrm{C}$ at the dose of $500 \mathrm{mg}$ OD as an add on therapy to enalapril $5 \mathrm{mg}$ BD causes significant reduction of both systolic and diastolic blood pressure, vitamin C 500mg OD supplementation to 
the standard anti-hypertensive drugs may produce better reduction of blood pressure, vitamin C $500 \mathrm{mg}$ may be recommended as an adjuvant to regular anti-hypertensive regimen to reduce cardiovascular and cerebrovascular risks associated with hypertension.

Funding: No funding sources Conflict of interest: None declared

Ethical approval: The study was approved by the Institutional Ethics Committee

\section{REFERENCES}

1. Harrison, Naomi DL, Fischer, Gordon H. Williams. Hypertensive vascular disease. In Dennis L Kasper, Editor. Principles of Internal Medicine, 16th Edition, US: Mc Graw Hill. 2005;2:1463-81.

2. Kearney PM, Whelton M, Reynolds K, Whelton PK, He J. Worldwide prevalence of hypertension: a systematic review. J Hypertens. 2004;22(1):11-9.

3. Chobanian AV, Bakris GL, Black HR, Cushman WC, Green LA, Izzo Jr JL, et al. Seventh report of the joint national committee on prevention, detection, evaluation, and treatment of high blood pressure. Hypertension. 2003;42(6):1206-52.

4. Ezzati M, Lopez AD, Rodgers A. Selected major risk factors and global and regional burden and complications of hypertension. Lancet. 2002;360:1347-60.

5. Stephen J. McPhee, Barry M. Massie, Systemic hypertension, Current medical diagnosis and treatment 2006, 45th Edition, McGraw Hill, Chapter 11. 41945

6. Chae CU, Lee RT, Rifai N, Ridker PM. Blood pressure and inflammation in apparently healthy men. Hypertension 2001;38:399-403.

7. Stumpf C, John S, Jukic J, Yilmaz A, Raaz D, Schmieder RE, et al. Enhanced levels of platelet P- selectin and circulating cytokines in young patients with mild arterial hypertension. J Hypertens. 2005;23(5):995-1000.

8. Schillaci G, Pirro M, Gemelli F. Increased C-reactive protein concentrations in hypertension: the role of systolic and pulse pressures. J Hypertens. 2003;21:1841-6.

9. Engstrom G, Lind P, Hedblad B, Stavenow L, Janzon L, Lindgarde F. Long-term effects of inflammationsensitive plasma proteins and systolic blood pressure on incidence of stroke. Stroke. 2002;33:2744-9.

10. Taddei S, Virdis A, Ghiadoni L, Magagna A, Salvetti A, Vitamin C improves endothelium-dependent vasodilation by restoring nitric oxide activity in hypertension, Circulation. 1998;97(22):2222-9.

11. Duffy SJ, Gokce N, Holbrook M, Huang A, Frei B, Keaney JF Jr, et al. Treatment of hypertension with ascorbic acid. Lancet. 1999;354:2048-9.

12. Block G, Mangel AR, Norkus EP, Patterson BH, Levander OA, Taylor PR. Ascorbic acid status and subsequent diastolic and systolic blood pressure. Hypertension. 2001;37:261-7.

13. Mullan BA, Young IS, Fee H, McCance DR. Ascorbic acid reduces blood pressure and arterial stiffness in type 2 diabetes. Hypertension. 2002;40:804-9.

14. Block G, Jensen C, Dietrich M, Norkus EP, Hudes M, Packer L. Plasma C-reactive protein concentrations in active and passive smokers: influence of antioxidant supplementation. J Am Col Nutrit. 2004;23(2):141-7.

Cite this article as: Singh V, Sourav U. Efficacy and tolerability of vitamin $\mathrm{C}$ as an add on therapy to standard antihypertensive regimen. Int J Basic Clin Pharmacol 2021;10:90-4. 